\title{
Accounting and auditing resources Sites for the investor, academic, and practitioner
}

$\mathbf{U}$ nderstanding and trust are factors critical to the stable working of the securities markets. Investors need to have accurate and relevant information about companies in order to invest wisely. Accounting professionals ensure investors have access to this information. Management accountants manage the internal nances and prepare reports for internal users; certi ed public accountants prepare nancial statements for external users and auditors review these statements and certify the accuracy of the reporting. Accounting standards developed by the Financial Accounting Standards Board (FASB) and the Governmental Accounting Standards Board (GASB), the U.S. standard setting bodies, ensure that reported nancial information is complete, consistent, comparable, and objective. Enforcement of the verity of the reported information is in the hands of the U.S. Securities and Exchange Commission (SEC), the agency authorized by Congress to protect investors against accounting fraud, the presentation of false or misleading information, and insider trading.

Since 1934, SEC has been a critical advocate for investors; however, the 2001 Enron disaster brought to light the need for additional regulation. In 2002, President Bush signed into law the landmark Sarbanes-Oxley Act, legislation that created the Public Company Accounting Oversight Board (PCAOB), a standard setting body that also provides oversight of large accounting rms and their auditors. The work of SEC and PCAOB protects investors against the chaos that would result from a lack of trust in the information investors have available to them to make responsible decisions when purchasing securities.

Accounting and auditing standards can seem confusing and overwhelming because of their variety and number. GAAP, or generally accepted accounting principles, are accounting rules set by FASB and GASB under the auspices of the U.S. Securities and Exchange Commission. Though companies may use different accounting methods (cash vs. accrual), public companies are expected to report their nancial information in accordance with GAAP s uniform standards and guidelines.

GAAS, Generally Accepted Auditing Standards, are guidelines auditors use when they conduct audits on companies. These guidelines are established by the Auditing Standards Board within American Institute of Certified Public Accountants (AICPA) and include general standards, standards of eldwork, and standards of reporting. SAS, Statements on Auditing Standards, are reports that represent preferable auditing standards and practices. These are issued by the auditing standards executive committee within the AICPA. Drafts of standards, or Exposure Drafts, are usually posted for public comment, and after these comments have been considered, the nal standard is released.

Colleen D. Anderson is head of reference services at Bryant University in Smithfield, Rhode Island, e-mail: canderso@bryant.edu

๑) 2008 Colleen D. Anderson 
Along with need to prevent major corporate scandals such as Enron, another main reason for the increasing number of accounting standards and regulations is the development of global business and securities markets. As business transactions increasingly occur across borders, and investors place money in global markets, accounting professionals need agreed upon international accounting standards that provide the same clarity, consistency, and transparency as U.S. standards. The International Accounting Standards Board (IASB) introduces and nalizes global accounting standards and partners with FASB to ensure fair and accurate international nancial reporting.

Investors, academics, and practitioners can now take advantage of the wealth of accounting and auditing information available on the Web through the standard setting and governmental sites. The following is a sampling of those sites with a note on the publications made available through each.

\section{Standard setting bodies}

Financial Accounting Standards Board (FASB). FASB was established in 1973 and is an independent designated body in the private sector for establishing nancial accounting and reporting standards that govern the preparation of nancial reports. Standards promulgated by FASB are recognized as authoritative by the Securities and Exchange Commission and by the American Institute of Certi ed Public Accountants. Fulltext publications available on the Web site under the FASB Pronouncements and EIFT Abstracts link include FASB pronouncements, Statements of Financial Accounting Standards, Statements of Financial Accounting Concepts, FASB Interpretations, FASB Technical Bulletins, and EIFT Abstracts. Access: http://www.fasb.org.

\section{Governmental Accounting Standards}

Board (GASB). Financial reporting at both the local and national levels of government provide information for making economic, political, and social decisions and also help ensure the government $s$ accountability to its citizens. Formed in 1984, GASB is an independent, private-sector, not-for-pro t organization that establishes and improves standards of state and local governmental accounting and nancial reporting. Summaries and status information on GASB documents including GASB Statements, GASB Concepts Statements, and GASB Interpretations are available under the Users link on the left banner. Access: http://www.gasb.org.

International Accounting Standards Board (IASB). IASB, founded in April 2001 by the International Accounting Standards Committee Foundation (IASCF), develops and sets global accounting standards known as International Financial Reporting Standards (IFRS). Final published standards consist of both International Financial Reporting Standards and standards issued by the Board of International Accounting Standards Committee (IASC) and known as International Accounting Standards. The Norwalk Agreement between the FASB and IASB commits to the development of compatible accounting standards that can be used for domestic and cross-border nancial reporting. Print copies of International Financial Reporting Standards and/or an online subscription to eIFRS can be purchased on the IASB Web site. Access: http://www.iasb.org/.

\section{Enforcement and regulatory bodies \\ The Public Company Accounting Oversight Board (PCAOB). PCAOB is a} private sector, nonpro t corporation created by the Sarbanes-Oxley Act of 2002 to oversee auditors of public companies. A Standard Advisory Group advises the Board on the establishment of auditing and related professional standards, and proposed standards are ordinarily published for public comment. After comments have been received and considered, the Board adopts a nal standard that must be approved by the Securities and Exchange Commission. The full text of Auditing Standards, Interim Standards, and Rules are available under the red Standards tab located on the banner at the top of the Web site. Access: http://www.pcaob.org/. 


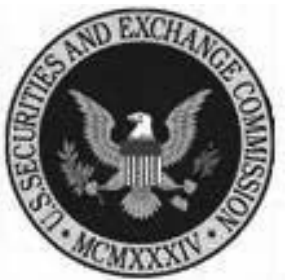

U.S. Securities and Exchange Commission (SEC). Most investors know the SEC site as the place to go to obtain required nancial

lings on public companies. Additional information relevant to accountants is located under the Information for box located in the upper righthand section of the homepage. Click on the Accountants option in the box to access a left bar menu with a link to Enforcement, which posts the Division of Enforcements selected Accounting and Auditing Enforcement Releases. These documents provide public access to enforcement actions. The Accounting link on the menu provides access to Staff Accounting Bulletins, which explain SEC s views regarding accounting-related disclosure practices. Access: http://www.sec.gov/.

\section{Professional associations}

American Accounting Association

(AAA). AAA is an organization of persons interested in accounting education and research. The association s mission is to promote worldwide excellence in accounting education, research, and practice. Its Web site includes free access to faculty development materials, job posting for teaching positions in accounting and auditing, and links to information about its journals and newsletters. The site also includes links to the AAA s journals: The Accounting Review, Issues in Accounting Education, and Accounting Horizons. Access: http://aaahq.org/.

American Institute of Certified Public Accountants (AICPA). With some 350,000 members, AICPA is the largest national professional organization of certi ed public accountants. The institute $s$ mission is to provide leadership as well as resources to CPAs to ensure standards of professionalism are established and maintained. The daily work of the organization involves helping to set standards for CPAs, developing and enforcing professional standards, and advocating for members before governmental and regulatory bodies. AICPA s involvement with FASB includes providing technical support, standard-setting, and guidelines in conjunction with FASB s work. Links to the full text of authoritative audit and attest standards are located under the Professional Resources tab on the Web site s left bar menu; select $A c$ counting and Auditing and then Authoritative Standards. AICPA also publishes and makes available a link to its well-known Journal of Accountancy, a journal of the latest news and developments in the eld of accounting. Access: http://www.aicpa.org/.

Institute of Internal Auditors (IIA). IIA is an international professional organization of 130,000 members working in the elds of internal auditing and risk management. The mission of IIA is to provide global leadership to the internal auditing profession by its work with certi cation, education, research, and technological guidance in the profession. Materials on IIA s site include information on how to become certi ed as an internal auditor, research reports (some free online), job postings, and a link to the site for the internal auditing profession s leading journal, Internal Auditor. Access: http://www.theiia.org/.

Institute of Management Accountants (IMA). Management accountants work inside organizations to ensure their economic viability. Their daily work includes tasks such as budgeting, forecasting, designing and monitoring business processes and internal controls, and managing information. IMA is a profes-


sional association supporting and empowering management accountants and nancial professionals. The association $\mathrm{s}$ Web site makes available information on preparing for and taking the Certi ed Management Accountant and the Certi ed Financial Manager exams. The site also includes a Research 
Center for Excellence that establishes and promotes best practices and an Ethics Center that links to IMA s Statement of Professional Practice. There is also a link to IMA s agship journal Strategic Finance, reporting on practices and trends in nance, accounting, and information management. Access: http://www.imanet.org/.

International Federation of Accountants (IFAC). This global organization for the accountancy profession represents 2.5 million accountants and works with 158 member organizations in 123 countries. IFAC includes and uses standard setting boards to develop international standards on ethics, auditing and assurance, education, and public sector accounting standards. IFAC also issues policy positions on topics of public interest. Its various committees post Exposure Drafts on the Web site for comment, and nal copies of standards can be purchased under the bookstore link. The Articles \& Speeches link provides free access to the full text of articles published by IFAC s leadership and other accounting professionals. Access: http://www.ifac.org/.

\section{Licensing board}

The National Association of State Boards of Accountancy (NASBA). Licensing and continuing education requirements for accountants are set by 55 individual state boards of accountancy (including the Commonwealth of Northern Mariana Islands, Guam, Puerto Rico, the Virgin Islands, and Washington, D.C.). NASBA serves as a forum for these boards and seeks to improve their effectiveness. Materials on the site include a State Board of Accountancy Listing, an Accountancy Licensing Library, which, for a minimal fee of $\$ 35$ for three months of access, permits users to view the requirements and procedures for their state s license(s), and information on state procedures and requirements for taking the CPA exam and the IQEX exam (an exam for internationally trained accountants seeking a reciprocal CPA designation in the United States). The site also provides a link to the Center for the Pubic Trust, which was center established to pro- mote ethical thinking and behavior. Access: http://www.nasba.org/.

\section{Blogs}

CPASense. Developed and maintained by Milt Baker, a retired but still active CPA. Blog content discusses diverse issues such as tax rules, nancial planning, or selecting a CPA. Much of the content has been taken from other prominent accounting and tax sites, tax publishers, or the IRS. Some of the entries focus on happenings in Michigan, where Baker resides. A ne selection of wellorganized content. Access: http://cpasense. blogspot.com.

Inside Sarbanes-Oxley. The implications of Sarbanes-Oxley in the world of nancial reporting are profound enough to give this blog a useful role in any accounting professionals life. The authors of this blog describe the 2002 legislation as The most demanding requirements placed on publicly traded companies since the Securities and Exchange Act of 1933 The blog updates readers using studies produced from governmental and standard setting bodies, as well as professional consultants. Topics covered include compliance, legislative actions, corporate governance, new proposed standards, and implications of U.S. accounting standards for international companies. Access: http://www.insidesarbanesoxley.com/.

\section{Sarbanes-Oxley}

\section{Portals}

AccountantsWorld. Sign up for a free lifetime membership to this accounting portal to access current news, stories, and articles on timely accounting topics. Distinctive features of the site include its Tools of the Trade and the Comprehensive Research \& Resources links. A link to the full text of one of the leading accounting journals, Abacus, is also provided. Access: http://www.accountingworld.com/.

Rutgers Accounting Web (RAW). RAW is a site from Rutgers University that posts current accounting research and links to an accounting portal. Work from the drop down 
box at the top of the site to view your desired content. The Accounting Research Directory link lists, evaluates, and categorizes major articles published between 1963 and present in nine leading accounting journals (registration is free). The Accounting Resources portal includes links to the Big Four accounting rms, journals and publications, state CPA associations, newly released books, and more. Access: http://raw.rutgers.edu/.

\section{SmartPros.com News \& Information}

Portal. SmartPro.com s News \& Information Portal is one of the most comprehensive sources available for accounting information. Access information by topic using the drop down box or the area of interest links located at the top of the page. Topics covered under areas of interest include full text news on domestic and international accounting, auditing, ethics and compliance, nancial planning, and more. The horizontal gray banner at the top of the page provides access to a Resource Library tab with links to Resources $\xi$ Tools for accountants (mostly standards setting bodies and associations), Newsletters EJournals, CPA Exam Study Guides \& Vendors, and an Auditing Glossary of Terms. Access: http://accounting. smartpros.com/.

\section{Miscellaneous}

Simple Studies Free Introduction to Accounting Lessons. Free accounting lessons presented in an understandable format that provide an introduction to the principles of nancial accounting. Modules include an Introduction to Accounting, Accounting for Accruals, Accounting for Deferrals, Doubleentry Account System, and more. Each module contains exercises to test your knowledge and a link to the site s Accounting Glossary. Access: http://www.simplestudies.com/.

Ten Steps to Accounting Research. Written by Peter Z. McKay, business librarian at the George A. Smathers Libraries at the University of Florida, this site explains how to organize the research process to nd information on a particular accounting topic. References to print and electronic resources and links to relevant literature and bodies are included throughout the text. Access: http://web.u ib.u .edu/cm/business/tutors /acctutor.htm.

\section{References}

Accounting Standards and Auditing Standards, (1998), published by Consultative Group to Assist the Poor (CGAP) at www. micro nancegateway.org/ les/2722_02722. pdf.

Facts About the IFA, (Nov. 2007) at www. ifac.org/MediaCenter/ les/Facts_About_IFAC. pdf.

The Investors Advocate: How the SEC Protects Investors, Maintains Market Integrity, and Facilitates Capital, (2007) at www.sec. gov/about/whatwedo.shtml.

A Roadmap for Convergence between IFRS and U.S. GAAP 2006-2008: A Memorandum of Understanding between the FASB and the IASB, (27 February 2006) at www. iasb.org/NR/rdonlyres/874B63FB-56DB-4B78 -B7AF-49BBA18C98D9/0/MoU.pdf. \#

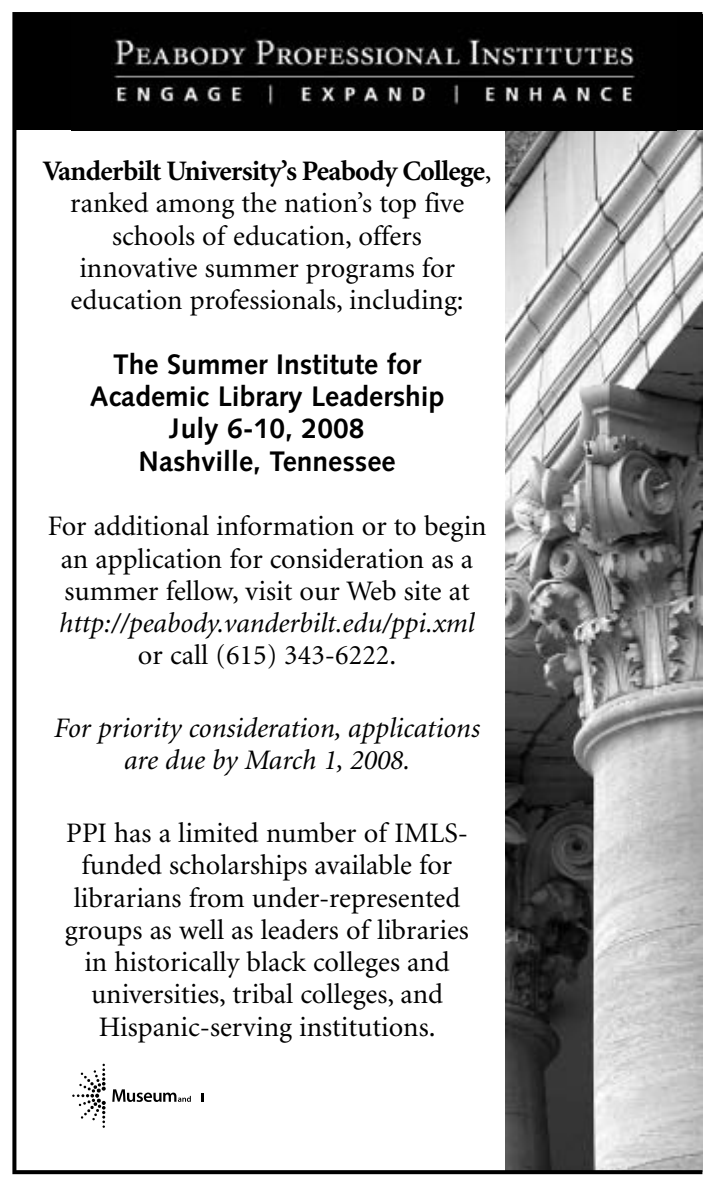

